\title{
Evaluasi nilai kecernaan in vitro bahan kering dan bahan organic biskuit biosuplemen daun katuk (Sauropus androgynus L.Merr) untuk sapi perah PFH
}

\section{Evaluation of digestibility values in vitro dry matter and organic matter biscuits biosuplemen leaf katuk (Sauropus androgynus L.Merr) for PFH dairy cattle}

\author{
Kartika Budi Utami*, Novita Dewi Kristanti \\ Program Studi Penyuluhan Peternakan, Sekolah Tinggi Penyuluhan Pertanian (STPP) \\ Malang
}

Submitted : 28 July 2017, Accepted : 31 Octoberr 2017

\begin{abstract}
ABSTRAK: Tujuan penelitian adalah mengevaluasi nilai kecernaan bahan kering dan bahan organik biskuit biosuplemen daun katuk (Sauropus androgynus L. Merr) secara in vitro. Materi penelitian yaitu biskuit biosuplemen yang terdiri atas bahan penyusun daun katuk, konsentrat sapi laktasi dan molases. Rancangan percobaan yang digunakan adalah rancangan acak lengkap (RAL) dengan 5 perlakuan dan 3 ulangan. P1: $10 \%$ daun katuk, 90\% konsentrat; P2: 20\% daun katuk, 80\% konsentrat; P3: 30\% daun katuk, 70\% konsentrat; P4: 40\% daun katuk, 60\% konsentrat; P5: 50\% daun katuk, 50\% konsentrat. Variabel yang diamati yaitu nilai kecernaan bahan kering dan bahan organik biskuit biosuplemen daun katuk. Data dianalisa menggunakan analisis sidik ragam (ANOVA). Hasil penelitian menunjukkan bahwa nilai kecernaan bahan kering dan bahan organik biskuit biosuplemen daun katuk secara in vitro masing-masing adalah $62,39 \%-72,80 \%$ dan $58,80 \%-70,00 \%$. Nilai kecernaan bahan kering dan bahan organik biskuit biosuplemen daun katuk tidak berbeda nyata $(\mathrm{P}>0,05)$ pada masing-masing perlakuan. Kesimpulan dari penelitian ini bahwa pemberian biskuit biosuplemen daun katuk belum mampu meningkatkan kecernaan bahan kering dan bahan organik secara in vitro.
\end{abstract}

Kata kunci: biskuit, biosuplemen, daun katuk

ABSTRACT: The aim of this research is to evaluate dry matter digestibility value and organic matter biscuits biosuplemen leaf katuk in vitro. The research materials were biosupplement biscuits, consist of katuk leaf, molasses and concentrate of lactation. The design used was complete randomized design (RAL) with 5 treatments and 3 replications. P1: 10\% leaf katuk, 90\% concentrate; P2: $20 \%$ katuk leaves, 80\% concentrate; P3: 30\% katuk leaves, 70\% concentrate; P4: 40\% katuk leaves, $60 \%$ concentrate; P5: $50 \%$ leaf katuk, $50 \%$ concentrate. The variables observed were dry matter digestibility and organic matter. Data were analyzed by using ANOVA. The results showed that the digestibility of dry matter and organic matter in vitro biscuits biosuplemen katuk respectively are $62.39 \%-72.80 \%$ and $58.80 \%$ $70.00 \%$. The dry matter digestibility value and the organic matter in vitro for each formulation treatment were not significantly different $(\mathrm{P}>0.05)$. The conclusion of this research is that biosupplement biscuits of katuk leaves has not been able to improve the digestibility of dry matter and organic matter in vitro.

Keywords: Biscuit, Biosuplement, Leaves katuk.

\section{PENDAHULUAN}

Sifat produksi susu sapi perah dipengaruhi oleh faktor genetik, lingkungan dan interaksi antara keduanya. Pakan merupakan faktor lingkungan yang memiliki peranan yang sangat besar dalam

*Corresponding author: kartikastppmalang@gmail.com

DOI: 10.21776/ub.jiip.2018.028.01.05 
menentukan kemampuan produksi susu sapi perah. Kebutuhan susu nasional bersumber dari sapi perah (Statistik Peternakan dan Kesehatan Hewan, 2015), sedangkan ratarata produksi susu sapi perah di peternak rakyat adalah 9-10 liter/ekor/hari dan masih berpotensi untuk ditingkatkan. Jenis pakan sapi perah yang diberikan oleh peternak adalah konsentrat dan rumput. Pada umumnya, peternak yang menjadi mitra atau anggota koperasi susu menggunakan konsentrat yang diproduksi oleh koperasi. Harga konsentrat cenderung mengalami kenaikan dan tidak sebanding dengan harga jual susu yang diperoleh, sehingga menyebabkan sapi perah memperoleh nutrisi pakan yang kurang berimbang dengan kebutuhan sapi perah laktasi. Sedangkan ketersediaan dan kandungan nutrisi rumput sangat bergantung pada musim.

Daun katuk (Sauropus androgynus L. Merr) dikenal sebagai tanaman obat yang berkhasiat untuk menyuburkan air susu baik pada manusia dan juga hewan. Para peneliti telah membuktikannya baik pada hewan percobaan maupun hewan ternak. Suprayogi (1993) melaporkan bahwa injeksi ekstrak daun katuk pada kambing ternyata mampu meningkatkan produksi susu sebesar 20\%. Injeksi ekstrak ini tidak mengubah kadar lemak, protein dan bahan kering tanpa lemak. Akbar, Sofjan dan Minarti (2013) melaporkan bahwa penambahan daun katuk dapat meningkatkan produksi air susu induk kelinci dan pertambahan bobot badan anak selama 3 minggu awal masa prasapih. Suriasih, et al., (2013) juga melaporkan bahwa penambahan ekstrak daun katuk pada sapi Bali dapat meningkatkan produksi susu 43,6\% dibandingkan dengan kontrol. Retnani, et al., (2015) mengungkapkan bahwa hormon prostaglandin yang berbentuk senyawa aktif dalam daun katuk dapat menyuburkan perkembangan sel sekretoris, yakni sel-sel penghasil ASI pada payudara ibu menyusui, sekaligus dapat memperlama jangka waktu produksi ASI. Sedangkan senyawa aktif lainnya membantu penyerapan asupan gizi dan meningkatkan metabolisme sehingga kapasitas produksi ASI meningkat, begitupula pada ternak.

Biskuit biosuplemen merupakan pakan suplemen sebagai pemacu produksi susu. Retnani, et al., (2015) menjelaskan bahwa biskuit biosuplemen pakan dibuat dari bahan-bahan yang mengandung zat aktif yang dapat meningkatkan produksi susu, memiliki tekstur yang kasar karena terdiri atas bahan baku campuran konsentrat dengan hijauan. Bahan baku campuran yang bisa dipakai dalam pembuatan biskuit biosuplemen pakan adalah bahan-bahan baku yang mengandung sumber serat, protein dan energi, serta bahan yang mengandung bioaktif yang terdapat pada hijauan dan legume seperti daun pepaya, daun katuk dan daun indigofera. Penelitian yang dilakukan oleh Retnani, et al., (2013) mengungkapkan bahwa biosuplemen daun pepaya dan indigofera $s p$ berpengaruh nyata terhadap produksi susu, dan semakin tinggi level pemberian biskuit biosuplemen semakin tinggi pula produksi susu kambing perah.

Penelitian tentang biskuit biosuplemen dengan penambahan daun katuk (Sauropus androgynus L. Merr) untuk meningkatkan produksi susu sapi perah belum banyak dilakukan, sehingga penelitian ini perlu dilakukan untuk mengevaluasi kecernaan biskuit biosuplemen daun katuk (Sauropus androgynus L.Merr) secara in vitro sebagai suplemen bagi sapi perah laktasi. 


\section{MATERI DAN METODE}

\section{Waktu dan tempat}

Penelitian telah dilaksanakan pada bulan Januari sampai dengan April 2017. Pembuatan biskuit biosuplemen daun katuk (Sauropus androgynus L. Merr) dan uji fisik biskuit telah dilakukan di Laboratorium Nutrisi dan Pakan Ternak STPP Malang. Analisa in vitro menggunakan metode Tilley and Terry. Analisa proksimat bahan penyusun biskuit biosuplemen daun katuk (Sauropus androgynus L. Merr) dan nilai kecernaan biskuit biosuplemen daun katuk (Sauropus androgynus L. Merr) dengan metode in vitro telah dilakukan di Laboratorium Nutrisi dan Pakan Ternak Universitas Brawijaya Malang.

\section{Materi penelitian}

Materi penelitian sebanyak 15 biskuit biosuplemen daun katuk (Sauropus androgynus L. Merr), terdiri atas 5 perlakuan dan 3 ulangan. Perlakuan didasarkan pada komposisi dasar penyusun biskuit biosuplemen yaitu terdiri dari $70 \%$ konsentrat dan $30 \%$ hijauan. Hijauan yang digunakan yaitu daun katuk. P1 mengandung $10 \%$ daun katuk dan $90 \%$ konsentrat; P2 mengandung 20\% daun katuk dan $80 \%$ konsentrat; P3 mengandung $30 \%$ daun katuk dan $70 \%$ konsentrat; P4 mengandung $40 \%$ daun katuk dan $60 \%$ konsentrat; P5 mengandung 50\% daun katuk dan 50\% konsentrat.

Alat yang digunakan adalah timbangan elektrik, plastik, nampan plastik, kayu pengaduk, kompor gas, cetakan biskuit, wajan, alat press manual dan oven otomatis. Proses pembuatan biskuit biosuplemen daun katuk (Sauropus androgynus L. Merr) sebagai berikut;

1) Persiapan bahan baku

Bahan baku yang disiapkan adalah molases, konsentrat sapi perah laktasi dan daun katuk (Sauropus androgynus L. Merr)

2) Penimbangan bahan

Semua bahan penyusun ditimbang sesuai dengan perlakuan. Berat bahan untuk satu biskuit adalah 600 gram. Masing-masing berat bahan sebagai berikut:

P1: Biskuit biosuplemen mengandung $10 \%$ daun katuk dan $90 \%$ konsentrat

P2: Biskuit biosuplemen mengandung $20 \%$ daun katuk dan $80 \%$ konsentrat

P3: Biskuit biosuplemen mengandung $30 \%$ daun katuk dan $70 \%$ konsentrat

P4: Biskuit biosuplemen mengandung $40 \%$ daun katuk dan $60 \%$ konsentrat

P5: Biskuit biosuplemen mengandung $50 \%$ daun katuk dan $50 \%$ konsentrat

3) Pencampuran

Tepung daun katuk (Sauropus androgynus L. Merr) dicampur dengan konsentrat dan molases kemudian hangatkan campuran ketiga bahan. Tepung kanji ditambahkan sebanyak 10\% dari berat bahan untuk merekatkan bahan penyusun biskuit, kemudian larutkan dengan $600 \mathrm{ml}$ air, dipanaskan hingga mendidih hingga terbentuk adonan biskut.

4) Pencetakan biskuit

Bahan baku yang sudah dicampur kemudian dimasukkan ke dalam cetakan biskuit, kemudian dipress menggunakan alat press manual serta dipanaskan di dalam oven selama 3 hari dengan suhu $50^{\circ} \mathrm{C}$. Diameter cetakan biskuit adalah $3 \mathrm{~cm}$ dan tebal $1,5 \mathrm{~cm}$. Sebaiknya pencetakan dilakukan 
segera setelah semua bahan tercampur merata.

5) Pendinginan

$$
\text { Biskuit yang sudah }
$$

terbentuk didinginkan dengan cara menyimpannya di udara terbuka (suhu kamar) kira-kira $25^{\circ} \mathrm{C}$. Kemudian dikemas ke dalam plastik dan ditutup rapat menggunakan sealer.

\section{Uji kualitas fisik biskuit}

\section{Ukuran partikel}

Ukuran partikel ditentukan dengan menggunakan metode screening, yaitu melewatkan bahan melalui ayakan seri (sieve shaker) yang mempunyai ukuran lubang ayakan semakin kecil.

Operasi screening dilakukan dengan jalan melewatkan material pada suatu permukaan yang banyak lubang atau openings dengan ukuran 325 mesh. Selanjutnya, akan diperoleh fraksi padatan yang tertahan ayakan (oversize) dan fraksi padatan yang lolos ayakan (undersize).

Masing-masing padatan yang diperoleh ditimbang dan dijumlahkan, setiap ayakan ukuran tertentu dihitung fraksi massa partikel yang lolos atau fraksi massa yang tertahan dan diameter reratanya, menggunakan rumus berikut:

Fraksi massa partikel yang tertinggal= berat partikel berat total campuran

fraksi massa partikel yang tertahan= berat partikel yang tertahan berat total campuran

\section{Densitas (kerapatan)}

Gelas ukur ditimbang dan dicatat beratnya. Sampel bahan pakan dimasukkan ke dalam gelas ukur lalu dipadatkan dengan kayu dan diusahakan seminimal mungkin adanya rongga antar bahan pakan. Kemudian berat sampel dengan volumenya dibandingkan dengan menggunakan rumus berikut:

Densitas :

$=\frac{\text { (berat sampel+wadah)-berat wadah }}{\text { Volume wadah }} \times 100 \%$

\section{Rancangan percobaan}

\section{a. Model matematika}

Rancangan percobaan yang digunakan adalah RAL (rancangan acak lengkap).

$$
Y_{i j}=\mu+P_{i}+\epsilon_{i j}
$$

Keterangan :

$\mathrm{i}=1,2,3, \ldots \ldots \ldots \ldots, \mathrm{p}$ dan $\mathrm{j}=1,2$, $3, \ldots \ldots \ldots \ldots, \mathrm{u}$

$\mathrm{Y}_{\mathrm{ij}}$ : Pengamatan perlakuan ke-i dan ulagan ke-j

$\mu$ : Rataan Umum

$\mathrm{P}_{\mathrm{i}}$ : Pengaruh perlakukan ke-i

$\epsilon_{\mathrm{ij}}$ : Galat perlakuan ke-I dan ulangan ke-j

\section{b. Perlakuan}

Rancangan yang digunakan adalah rancangan acak lengkap (RAL) dengan 5 perlakuan dan 3 ulangan. Perlakuan didasarkan pada komposisi dasar penyusun biskuit biosuplemen yaitu terdiri dari $70 \%$ konsentrat dan $30 \%$ hijauan. Hijauan yang digunakan yaitu daun katuk. Biskuit biosuplemen diberikan kepada ternak sebagai suplemen sehingga berat total sebuah biskuit adalah 600 gram.

P1: Biskuit biosuplemen mengandung 10\% daun katuk dan $90 \%$ konsentrat P2: Biskuit biosuplemen mengandung 20\% daun katuk dan $80 \%$ konsentrat P3: Biskuit biosuplemen mengandung 30\% daun katuk dan $70 \%$ konsentrat 
P4: Biskuit biosuplemen mengandung $40 \%$ daun katuk dan $60 \%$ konsentrat

P5: Biskuit biosuplemen mengandung 50\% daun katuk dan 50\% konsentrat

\section{c. Variabel yang diamati}

Variabel yang diamati yaitu kualitas fisik biskuit dan nilai kecernaan bahan kering dan bahan organik biskuit biosuplemen daun katuk (Sauropus androgynus L. Merr).

\section{d. Analisa data}

Data yang diperoleh dianalisa dengan menggunakan sidik ragam ANOVA dan jika ada perbedaan antara perlakuan dilakukan uji lanjut Duncan.

\section{HASIL DAN PEMBAHASAN}

Nilai kecernaan bahan kering dan bahan organik biskuit biosuplemen daun katuk yang diperoleh selama penelitian ini lebih rendah dibandingkan dengan yang telah dilaporkan oleh Retnani, dkk (2012) secara berurutan yaitu $82,05 \% \pm 0,30 \%$ dan $81,34 \% \pm 0,68 \%$. Rendahnya kecernaan biskuit biosuplemen daun katuk menunjukkan bahwa suplemen mengandung zat-zat makanan dalam bentuk yang tidak dapat dicerna dalam saluran pencernaan.

Hasil analisa sidik ragam menunjukkan bahwa nilai kecernaan bahan kering dan bahan organik biskuit biosuplemen daun katuk secara in vitro untuk masing-masing perlakuan formulasi tidak berbeda secara nyata $(\mathrm{P}>0,05)$. Hasil pengukuran kecernaan bahan kering dan bahan organiak dari masing-masing perlakuan disajikan pada Tabel 1 .

Tabel 1. Rataan nilai daya cerna bahan kering dan bahan organik

\begin{tabular}{ccc}
\hline Biskuit & Rataan daya cerna bahan kering & Rataan daya cerna bahan organik \\
\hline $\mathrm{P}_{1}$ & $70,10 \pm 0,81$ & $66,31 \pm 0,44$ \\
$\mathrm{P}_{2}$ & $70,22 \pm 0,32$ & $67,93 \pm 1,80$ \\
$\mathrm{P}_{3}$ & $68,00 \pm 2,46$ & $64,69 \pm 1,97$ \\
$\mathrm{P}_{4}$ & $68,83 \pm 2,06$ & $64,65 \pm 1,84$ \\
$\mathrm{P}_{5}$ & $68,18 \pm 5,30$ & $64,33 \pm 4,89$ \\
\hline
\end{tabular}

Salah satu faktor yang menyebabkan nilai daya cerna bahan kering dan bahan organik secara in vitro yang rendah yaitu ukuran partikel biskuit biosuplemen daun katuk yang lolos ayakan sieve sebesar 0,044 mikrometer dan tergolong sangat halus. Hal ini sejalan dengan pendapat Utomo dan Soejono (1987) bahwa kehalusan penggilingan pakan menyebabkan berkurangnya ruminasi. Penggilingan dan pembuatan pellet menaikkan kepadatan dan menurunkan ukuran partikel sehingga mengurangi kerja pencernaan dan ruminasi, bahkan penggilingan total terhadap pakan menyebabkan ruminasi berhenti dan heat increment turun. Sifat fisik diduga dipengaruhi saat proses pembuatan biskuit. Alat pressing yang digunakan adalah manual dan pressing tidak dilakukan secara bersamaan dengan proses pemanasan saat cooking. Hal ini menyebabkan biskuit biosuplemen daun katuk memiliki densitas rendah, selain itu ukuran partikel biskuit biosuplemen daun katuk tergolong sangat halus. Sifat fisik biskuit biosuplemen daun katuk di dalam penelitian ini meliputi nilai densitas (kerapatan) dan ukuran partikel disajikan pada Tabel 2 dan Tabel 3. 
Tabel 2. Rata-rata nilai kerapatan biskuit biosuplemen daun katuk

\begin{tabular}{cc}
\hline Perlakuan & Rata-rata kerapatan $\left(\mathbf{g r} / \mathbf{c m}^{\mathbf{3}}\right)$ \\
\hline $\mathrm{P}_{1}$ & $0,28 \pm 0,03$ \\
$\mathrm{P}_{2}$ & $0,28 \pm 0,02$ \\
$\mathrm{P}_{3}$ & $0,27 \pm 0,05$ \\
$\mathrm{P}_{4}$ & $0,21 \pm 0,01$ \\
$\mathrm{P}_{5}$ & $0,24 \pm 3,45$ \\
\hline
\end{tabular}

Tabel 2 menunjukkan bahwa ratarata nilai kerapatan biskuit biosuplemen pada semua perlakuan termasuk kategori kerapatan kecil dibandingkan dengan yang pernah dilaporkan oleh Retnani, et al., (2012) yaitu sebesar $0,64 \pm 0,03 \mathrm{gr} / \mathrm{cm}^{3}$. Susanti dan Nurhidayat (2008) menjelaskan bahwa bahan pakan dengan nilai densitas kecil akan menempati ruang simpan besar karena kemampuan pemadatan bahan rendah sehingga bahan pakan dengan densitas kecil memerlukan ruang simpan baik karung, gudang dan ruang saluran cerna yang besar pada berat yang sama. Densitas atau kerapatan adalah suatu ukuran kekompakan partikel dalam lembaran dan sangat tergantung pada kerapatan bahan baku yang digunakan serta besarnya tekanan kempa yang diberikan selama proses pembuatan lembaran dengan menentukan atau mengukur berat sampel untuk setiap satu satuan volume sampel (Suryani, 1986).

Di dalam penelitian ini, ukuran partikel biskuit ditentukan dengan menggunakan metode screening dengan menggunakan sieve shaker berukuran 325 mesh sehingga partikel yang akan tertinggal (lolos) memiliki diameter 0,044 mikrometer. Ukuran partikel biskuit biosuplemen daun katuk tergolong lembut/sangat halus dibandingkan dengan hasil penelitian terdahulu yaitu 4,80/kasar (Retnani, Permana dan Purba, 2014).

Tabel 3. Rata-rata nilai fraksi massa partikel biskuit biosuplemen daun katuk

\begin{tabular}{ccc}
\hline \multirow{2}{*}{ Perlakuan } & \multicolumn{2}{c}{ Fraksi massa partikel $(\%)$} \\
\cline { 2 - 3 } & Tertinggal & Tertahan \\
\hline $\mathrm{P}_{1}$ & $0,05 \pm 0,01$ & $0,94 \pm 0,01$ \\
$\mathrm{P}_{2}$ & $0,04 \pm 0,01$ & $0,96 \pm 0,02$ \\
$\mathrm{P}_{3}$ & $0,05 \pm 0,01$ & $0,95 \pm 0,02$ \\
$\mathrm{P}_{4}$ & $0,05 \pm 0,01$ & $0,95 \pm 0,01$ \\
$\mathrm{P}_{5}$ & $0,07 \pm 0,02$ & $0,92 \pm 0,02$ \\
\hline
\end{tabular}

Tabel 3 menunjukkan bahwa fraksi massa partikel biskuit biosuplemen daun katuk yaitu $95 \%$ fraksi massa partikel tertahan dan biskuit biosuplemen daun katuk memiliki nilai kerapatan yang lebih rendah sehingga memiliki nilai kecernaan yang rendah. Pakan yang memiliki nilai kerapatan besar atau amba akan cepat memenuhi saluran pencernaan ternak sehingga jumlah konsumsi ternak akan rendah. Jumlah konsumsi berbanding terbalik dengan nilai kecernaan. Jika konsumsi ternak rendah maka pakan akan mempunyai waktu yang cukup lama dalam saluran pencernaan, laju digesta akan relatif lebih lambat yang menyebabkan waktu retensi dalam rumen bertambah dan terjadinya peningkatan proses fermentasi sehingga banyak digesta yang didegradasi oleh mikroba rumen dan kecernaan akan tinggi. 


\section{KESIMPULAN}

Berdasarkan hasil penelitian, dapat disimpulkan bahwa pemberian biskuit biosuplemen daun katuk belum mampu meningkatkan kecernaan bahan kering dan bahan organik secara in vitro sebagai suplemen untuk sapi perah.

\section{DAFTAR PUSTAKA}

Akbar, M, Sofjan, O dan Minarti, S. 2013. Produksi Air Susu Induk dan Tingkat Mortalitas Anak Kelinci yang Diberi Pakan Tambahan Tepung Daun Katuk (Sauropus Androgynus L. Merr). JITV Vol. 18 No. 4 Th. 2013: 233-238. Universitas Brawijaya. Malang.

Anggorodi, R.. 1984. Ilmu Makanan Ternak Umum. PT Gramedia. Jakarta.

Kencana, E. D, Hasnelly dan Anjarsari, B. 2016. Pengaruh Suhu dan Lama Pengeringan Terhadap Karakterisitik Teh Herbal Daun Katuk (Sauropus adrogynus L. Merr). Jurnal penelitian tugas akhir. Universitas Pasundan.

McDonald, P., R. Edwards, J. Greenhalgh, and C. Morgan. 2002. Animal Nutrition. 6th Edition. Longman Scientific \& Technical, New York.

Pell, A.NND.J.R. Cherney and J.S. Jones. 1993. Technical note: Forage InVitro Dry Matter Digestibility as influenced by Fibre Source in TheDonor Cow Diet. J. Animal Sci 71.

Retnani, Y, Permana, I. G, Herawaty, L dan Komalasari, N. R. 2012. Biskuit Biosuplemen Pakan untuk Meningkatkan Produktivitas Kambing Perah. Prosiding Seminar Hasil-hasil Peneltian IPB 2012. Institut Pertanian Bogor. Bogor.
Retnani, Y, Permana, I. G dan Purba, L.C. 2014. Physical Characteristic and Palatability of Biscuit Bio-supplement of Dairy Goat. Pakistan Journal of Biological Science 17 (5) : 725-729, 2014. ISSN 1028-8880/ DOI: 10.3923/pjbs.2014.725.729 @2014 Asian Network for Scientific Information

Santoso, U. 2013. Katuk, Tumbuhan Multikhasiat. ISBN. 978-602-9071-122. Badan Penerbit Fakultas Pertanian (BPFP) Unib. Bengkulu.

Suriasih, K, Sucipta, N, Siti, W dan Sukmawati, M.S. 2015. Effect of Katuk Leaf (Sauropus androgynus) Extract Supplementation on Milk Quality and Yield of Bali Cow Fed Rice Straw and Natural Grass Basal Diet. Journal of Biology, Agriculture and Healthcare. ISSN 2224-3208 (Paper) ISSN 2225093X (Online). Vol.5, No.24, 2015.

Suryani, A. 1986. Pengaruh tekanan pengempaan dan jenis perekat dalam pembuatan arang briket dari tempurung kelapa sawit (Elais quinensis Jacq). Proyek Peningkatan dan Pengembangan Perguruan Tinggi. Institut Pertanian Bogor, Bogor.

Sutardi, T. 1979. Ketahanan protein bahan makanan terhadap degradasi mikroba rumen dan manfaatnya bagi peningkatan produktivitas ternak. Prosiding Seminar Penelitian dan Penunjang Peternakan. LPP Institut Pertanian Bogor, Bogor.

Tillman, A. D., H. Hartadi, S. Reksohadiprojo,S. Prawirokusumo dan S. Lendosoekodjo. 1991. Ilmu Makanan Ternak Dasar. Cetakan 
Kedua Peternakan. Gajah Mada University Press, Yogyakarta.

Trisyulianti, E. 1998. Pembuatan wafer rumput gajah untuk pakan ruminansia besar. Seminar Hasil-Hasil Penelitian Institut Pertanian Bogor. Jurusan Ilmu Nutrisi dan Makanan Ternak, Fakultas Peternakan, Institut Pertanian Bogor, Bogor.

Utomo, R dan Soejono, M. 1987. Pengaruh Ukuran Partikel Pakan terhadap Kecernaan. Buletin Peternakan Vol 11, No 1 (1987) . pISSN: 0126-4400, eISSN: 2407-876X. DOI: https://doi.org/10.21059/buletinpetern ak.v11i1.1798. 